ORIGINAL PROF-2219

\title{
HAPLOTYPES AND GENOTYPES;
}

THE FREQUENCY OF RHESUS ALLELES, HAPLOTYPES AND GENOTYPES IN MAJOR SAKAK CITY POPULATION, ALJOUF REGION, SAUDI ARABIA

Dr. Hamid Mahmood, Dr. Sitara Hassan, Dr. Hashim Riaz, Dr. Waseem Akhtar

ABSTRACT... Rh-D distribution varies worldwide. Objectives: The aim of this study was to document the frequency of Rhesus alleles, haplotypes and genotypes in Aljouf region, Sakaka. The EE genotype is not generally represented in the Aljouf province, and DcE/Ce genotypes are the shared (30.8\%), while Dce/Dce and Dce/ce genotypes are less familiar (1.4\%). Results: The frequency distribution of Rh haplotypes among Aljouf population in the present study $\operatorname{CDE}(0.701)$ has the highest observed frequency followed by $\mathrm{Cde}(0.250)$, $\mathrm{cDe}(0.116)$ and $\mathrm{CDe}(0.040), \mathrm{CDE}(0.028)$, cde $(0.021)$ and $\mathrm{cdE}(0.008)$. The data generated during this study would be important, a base line for advance to be catalogued by molecular rather than serological criteria, and of polymorphisms between RHD and RHCE, which will be a useful for DNA typing and to provide the development of suitable DNA techniques.

Key word: Blood groups, Rhesus, Haplotypes, Genotypes

Article Citation

Mahmood H, Hassan S, Riaz H, Akhtar W. Haplotypes and Genotypes; The frequency of rhesus alleles, haplotypes and genotypes in major Sakak city population, Aljouf region, Saudi Arabia. Professional Med J 2013;20(5): 832-839.

\section{INTRODUCTION}

The Rhesus blood group system (ISBT 004) is the common complex blood group system; comprising 46 antigens numbered $\mathrm{RH} 1$ to $\mathrm{RH} 53$ with seven numbers obsolete1. It is the most polymorphic human blood group, and next to $\mathrm{ABO}$. The clinically significant in transfusion medicine. In Rh blood system, 18 phenotypes can be distinguished by using five kinds of anti-D,C,C,E,e ${ }^{1}$. Eight basic haplotypes are formed from primitive haplotype $\mathrm{cDe}$ by a series of duplication, point mutation and recombination events ${ }^{2,3}$. The frequencies of these haplotypes vary among different populations. From serological results, it is often impossible to determine the true genotype of an individual and phenotypes are sometimes symbolized as the most probable genotypes deduced from known haplotype frequencies'. Serologically similar phenotypes have different molecular backgrounds ${ }^{4}$. The $D$ unwilling phenotype has either rh specific sequences positive or rh complete deletion. The cumulative frequency of various $\mathrm{rh}$ alleles in $\mathrm{D}$ pessimistic Europeans is $1: 1,500^{5}$. However, in Africans and Asians, the frequencies are much different. In D gloomy Han Chinese, about 19.9\%(all $\mathrm{C}+$ ) have a grossly intact $\mathrm{Rh}, 168 \%$ carry at least one rh exon $^{6}$, and in D negative African, around $82 \%$
African have RHDW and RHD-CE-D hybrid gene. The antigen $D$ is the most immunogenic of the $R h$ antigens and the clinically most important'. Anti-D usually is introduced after blood transfusion or pregnancy. About $85 \%$ of $D$ negative recipients produce anti-D following transfusion of $200 \mathrm{ml}$ or more of D clear red cells ${ }^{7}$ and as little as $0.1 \mathrm{ml}$ of $\mathrm{D}$ favorable blood can immunize $D$ cynical recipient. Even weak $D$ type $2^{8}$ or DEL phenotype ${ }^{9}$ red cells can cause $D$ unwilling recipient to produce anti-D. Clinically, anti-D has the potential to cause hemolytic disease of the newborn, transfusion reactions and autoimmune hemolyticus disease. Knowledge of Rh phenotypes in given population is relevant for better planning and management of a blood bank; to find compatible blood for patients needing multiple blood transfusions, which would resolve the blood transfusion needs of recipients. A random survey for Rh in Aljouf, Sakaka population was revealed $\mathrm{rh}$ allele distribution characters and defines its frequencies; it was also be benefit for accumulating human genetic data and useful guidelines for transfusion strategies.

\section{METHODOLOGY}

A total of 422 subjects (unrelated individuals) of both sex (male and female) and all ages were included 
within this study over two years. Essential information was noted and recorded on a printed form. Subject blood samples were collected under aseptic condition from an anti-cubital vein for determination of Rhesus blood groups. Rhesus blood alleles, haplotypes and Genotype's grouping were determined by ID-Card "DiaClon contains monoclonal anti $\mathrm{C}$, anti $\mathrm{C}$, anti $\mathrm{D}$, anti E, anti e [cell lines LM 297/628 (LA-2) and Preservative: $<0.1 \%$ NaN3. EDTA-anticoagulated blood samples (3-5 ml) were drawn from 422 unrelated Saudi Arabian populations after obtaining their consent. All study groups were living in Aljouf Region, Sakaka, chosen at random according to such characters as name, residence, appearance and tribe. The collectors labeled the samples anonymously to guarantee unconnected testing. The samples were sent to hematology laboratory, College of applied medical science, Aljouf University, Aljouf, Sakaka for Rhesus alleles and phenotype determination. The Rhesus alleles and haplotypes were determined by using monoclonal reagents according to the manufacturer's instructions. ID-Card "DiaClon anti-D ( $\lg M$ or $\lg G$ ) was used. The other rhesus antigens were determined using monoclonal or oligoclonal reagents (anti-D, anti-C, anti-C, anti-E, and anti-c). The genotype was determined using either: the sample was considered homozygous for Rh, if two unusual rh, alleles detected, when there was a discrepancy between them, we choose rh sequencing result. Alternatively, if distinctive combinations of genotypes could explain a given sample, the most likely genotype was chosen as the common plausible explanation.

\section{RESULTS}

A total of four hundred twenty two healthy Arab ethnic male persons from five common tribes in Aljouf( Sharary: $n=134$, Shamari: $n=48$, Rwealy: $n=126$, Enazy: $n=106$ and Sarhany: $n=8$ ) in different age groups were randomly selected from Primary Health Centers (PHC) of Sakaka city, Jouf Province of Saudi Arabia. The Al Jouf Province forms a vital position of the North Arabian and Syrian desert and is enclosed by sandstone hills; its oases have played an significant role in the contacts between the Arabs in the Peninsula and the people of the Fertile Crescent. Al Jouf was an extremely consequential center and a summer camping ground for the nomads in ancient history. It was a confluence of various cultures. Sakaka, the capital from the province. The most common ABO blood group among the study groups was grouped 0; Enazy (43.4\%), Rwealy(40.5\%), Shamari(45.8\%), Sharary (47.0\%) and Sarahny(50.0\%) as shown in table I.

Table II shows the frequency of the five $\mathrm{Rh}$ antigens in the population. The alleles were found as follows: e $384(91.0 \%)$, D 393(93.1\%), C 263(62.3\%), c $176(41.7 \%)$ and $E$ 188(44.5\%). These alleles were varied between the five ethnic groups of Aljouf province. The studying of some genotypes of the Rhsystem, high frequency distribution 192(45.5\%)) of the Ee version was identified. The number of the cc

\begin{tabular}{|c|c|c|c|c|c|}
\hline Blood groups & \multicolumn{5}{|c|}{ Ethnic group, $\mathbf{n ( \% )}$} \\
\hline & $\begin{array}{c}\text { Enazy } \\
(\mathbf{n = 1 0 6 )}\end{array}$ & $\begin{array}{c}\text { Rwealy } \\
(\mathbf{n = 1 2 6})\end{array}$ & $\begin{array}{c}\text { Shamari } \\
(\mathbf{n = 4 8 )}\end{array}$ & $\begin{array}{c}\text { Sharary } \\
(\mathbf{n = 1 3 4 )}\end{array}$ & $\begin{array}{c}\text { Sarhany } \\
(\mathbf{n = 8})\end{array}$ \\
\hline $\mathrm{A}$ & $33(31.1)$ & $43(34.1)$ & $15(31.3)$ & $46(34.3)$ & $2(25.0)$ \\
\hline $\mathrm{B}$ & $20(18.9)$ & $23(18.3)$ & $7(14.6)$ & $15(11.2)$ & $1(12.5)$ \\
\hline 0 & $46(43.4)$ & $51(40.5)$ & $22(45.8)$ & $63(47.0)$ & $4(50)$ \\
\hline AB & $7(6.6)$ & $9(7.1)$ & $4(8.3)$ & $10(7.5)$ & $1(12.5)$ \\
\hline
\end{tabular}


genotype carrier was a little lesser $6(1.42 \%)$. The Cc genotype carriers' frequency made up 170(40.3\%). As for the ee genotype frequency; it equaled $155(36.7 \%)$ and CC frequency up to be $93(22.0 \%)$. It is to be mentioned that the EE genotype is not generally represented in the Aljouf province (Table III).

The Rh-antigens complex's frequencies were shown in table 4. Only people belonging to Rwealy tribe have the complex DCce (31.7\%). In Shamary tribe DCcEe is very dominant $(66.7 \%)$. Rh null was high among Rwealy and Enazy $8.7 \%$ and $9.4 \%$ respectively, while DcEe, DcE and ce antigen complexes were absent from all stud groups. Table IV. The frequency distribution of $\mathrm{Rh}$ haplotypes among Aljouf population was depicted in Table V. In the present study, $\operatorname{CDE}(0.701)$ has the highest observed frequency followed by Cde (0.250), cDe (0.116) and CDe (0.040), $\mathrm{cDE}(0.028)$, cde(0.021) and $\operatorname{cdE}(0.008)$ respectively as shown in table $\mathrm{V}$. Table $\mathrm{VI}$ showed the $\mathrm{Rh}$ genotypes expected frequencies were shown in table 6. DCe/DcE, DCe/cE and DcE/Ce genotypes were the joint (30.8\%), while Dce/Dce and Dce/ce genotypes were less communal (1.4\%).

\section{DISCUSSION}

The Rhesus (Rh)D was, in fact, the fourth blood group system to be discovered and later ranked second to $\mathrm{ABO}$ system in terms of clinical importance ${ }^{10}$. Both are of equal importance in simple and forensic medicine. The study of $\mathrm{Rh}$ blood group is important in simple practice it was felt desirable to find out the prevalence of Rh phenotypes and genotypes in Al-Jouf Province of the Saudi Arabia from where no earlier serological data

\begin{tabular}{|c|c|c|c|c|c|c|}
\hline $\begin{array}{c}\text { Antigen } \\
\text { present }\end{array}$ & Sarhany (n=8) & Enazy (n=106) & $\begin{array}{c}\text { Rwealy } \\
(\mathbf{n = 1 2 6})\end{array}$ & $\begin{array}{c}\text { Shamari } \\
(\mathbf{n = 4 8 )}\end{array}$ & $\begin{array}{c}\text { Sharary } \\
(\mathbf{n = 1 3 4})\end{array}$ & $\begin{array}{c}\text { Total } \\
(\mathbf{N}=\mathbf{4 2 2})\end{array}$ \\
\hline $\mathrm{D}$ & $8(100 \%)$ & $96(90.6 \%)$ & $115(91.3 \%)$ & $47(98.0 \%)$ & $127(94.8 \%)$ & $393(93.1 \%)$ \\
\hline C & $8(100 \%)$ & $58(54.7 \%)$ & $66(52.4 \%)$ & $39(81.25 \%)$ & $92(68.7 \%)$ & $263(62.3 \%)$ \\
\hline E & $8(100 \%)$ & $32(30.2 \%)$ & $26(20.6 \%)$ & $38(79.17 \%)$ & $84(62.7 \%)$ & $188(44.5 \%)$ \\
\hline C & $4(50 \%)$ & $24(22.4 \%)$ & $72(57.1 \%)$ & $32(66.7 \%)$ & $44(32.8 \%)$ & $176(41.7 \%)$ \\
\hline e & $8(100 \%)$ & $94(88.9 \%)$ & $100(79.4 \%)$ & $48(100 \%)$ & $134(100 \%)$ & $384(91.0 \%)$ \\
\hline
\end{tabular}

Table-II. The frequencies of rh alleles in Aljouf region population of the Saudi Arabia

\begin{tabular}{|c|c|c|c|c|c|c|}
\hline $\begin{array}{c}\text { Antigen } \\
\text { present }\end{array}$ & Sarhany (n=8) & Enazy (n=106) & $\begin{array}{c}\text { Rwealy } \\
(\mathbf{n = 1 2 6})\end{array}$ & $\begin{array}{c}\text { Shamari } \\
\mathbf{( n = 4 8 )}\end{array}$ & $\begin{array}{c}\text { Sharary } \\
(\mathbf{n = 1 3 4})\end{array}$ & $\begin{array}{c}\text { Total } \\
(\mathbf{N}=\mathbf{4 2 2})\end{array}$ \\
\hline CC & $4(50 \%)$ & $34(32 \%)$ & - & $7(14.6 \%)$ & $48(35.9 \%)$ & $93(22.0 \%)$ \\
\hline CC & $4(50 \%)$ & $24(22.6 \%)$ & $66(52.4 \%)$ & $32(66.7 \%)$ & $44(32.8 \%)$ & $170(40.3 \%)$ \\
\hline CC & - & - & $6(4.8 \%)$ & - & - & $6(1.42 \%)$ \\
\hline EE & - & - & - & - & - & - \\
\hline Ee & $8(100 \%)$ & $32(30.2 \%)$ & $26(20.6 \%)$ & $38(79.2 \%)$ & $88(62.7 \%)$ & $192(45.5 \%)$ \\
\hline ee & - & $62(58.5 \%)$ & $34(27.0 \%)$ & $9(18.8 \%)$ & $50(37.3 \%)$ & $155(36.7 \%)$ \\
\hline
\end{tabular}

Table-III. Distribution peculiarities of the CC, CC, CC, Ee, EE, ee genotypes in the Aljouf region population of the Saudi Arabia 


\begin{tabular}{|c|c|c|c|c|c|c|c|c|}
\hline $\begin{array}{l}\text { Antigen } \\
\text { present }\end{array}$ & $\begin{array}{c}\text { Sarhany } \\
(n=8)\end{array}$ & $\begin{array}{c}\text { Enazy } \\
(n=106)\end{array}$ & $\begin{array}{c}\text { Rwealy } \\
(n=126)\end{array}$ & $\begin{array}{c}\text { Shamari } \\
(n=48)\end{array}$ & $\begin{array}{l}\text { Sharary } \\
(n=134)\end{array}$ & $\begin{array}{c}\text { Total } \\
(\mathrm{N}=422)\end{array}$ & Whites* & $\underset{*}{\text { Blacks }}$ \\
\hline $\mathrm{DCcEe}$ & $4(50 \%)$ & $24(22.6 \%)$ & $26(20.6 \%)$ & $32(66.7 \%)$ & $44(32.8 \%)$ & $130(30.8 \%)$ & $13.2 \%$ & $4.2 \%$ \\
\hline DCEe & $4(50 \%)$ & 8 (7.5\%) & - & $6(12.5 \%)$ & $40(29.9 \%)$ & $58(13.7 \%)$ & - & - \\
\hline DCce & - & - & $40(31.7 \%)$ & - & - & $40(9.5 \%)$ & $34.7 \%$ & $24.6 \%$ \\
\hline $\mathrm{DCe}$ & - & $6(5.66 \%)$ & - & $1(2.1 \%)$ & $8(6.0 \%)$ & 35 (8.3\%) & $19.3 \%$ & $3.6 \%$ \\
\hline Dce & - & - & $6(4.8 \%)$ & - & - & $6(1.4 \%)$ & $3.2 \%$ & $42.3 \%$ \\
\hline $\mathrm{De}$ & - & $36(34 \%)$ & 28 (22.2\%) & $8(16.7 \%)$ & $35(26.1 \%)$ & 107 (25.4\%) & - & - \\
\hline D & - & $2(1.9 \%)$ & 15 (11.9\%) & - & - & $17(4.0 \%)$ & - & - \\
\hline$E$ & - & - & - & - & 7 (5.2\%) & $7(1.7 \%)$ & - & - \\
\hline null & - & $10(9.4 \%)$ & $11(8.7 \%)$ & $1(2.1 \%)$ & - & $22(5.2 \%)$ & - & - \\
\hline $\mathrm{DcEe}$ & - & - & - & - & - & - & $11.5 \%$ & $15.4 \%$ \\
\hline DcE & - & - & - & - & - & - & $2.3 \%$ & $1.4 \%$ \\
\hline ce & - & - & - & - & - & - & $15 \%$ & $7 \%$ \\
\hline
\end{tabular}

\begin{tabular}{|c|c|c|}
\hline Expected haplotypes* $^{*}$ & Frequency & Phenotypes \\
\hline CDE & 0.701 & $\mathrm{Rz}$ \\
\hline Cde & 0.250 & $\mathrm{r}^{\prime}$ \\
\hline CDe & 0.116 & $\mathrm{R}_{0}$ \\
\hline CDe & 0.040 & $\mathrm{R}_{1}$ \\
\hline CDE & 0.028 & $\mathrm{R}_{2}$ \\
\hline cde & 0.021 & $\mathrm{r}$ \\
\hline CdE & \multicolumn{2}{|c|}{0.008} \\
\hline Table-V. The most probable haplotypes frequencies among Aljouf region population \\
* calculated according to Mourant et al 1976. \\
2 (cde) = 2(176/422*29/422*383/422)
\end{tabular}

are available. In our study, blood group 0 was found predominant and $A B$ was stood on the lowest side among the five ethnic population in aljouf. Similar distribution pattern of $A B O$ blood groups was reported in Egypt, Jordon, Nigeria, Kenya and Eastern region of
Saudi Arabia. However, other countries such as Syria, Lebanon, Israel and Jordan have an unusual $A B O$ distribution pattern in which blood group $A$ was predominant. This may be attributed to their distinct ethnic background, besides sampling error, and 


\begin{tabular}{|c|c|c|c|}
\hline & $\begin{array}{c}\text { Total } \\
(n=422)\end{array}$ & $\begin{array}{c}\text { Expected } \\
\text { genotypes } \\
\text { (Fisher) }\end{array}$ & $\begin{array}{c}\text { Expected } \\
\text { genotypes } \\
\text { (Weiner) }\end{array}$ \\
\hline DCcEe & $130(30.8 \%)$ & $\begin{array}{c}\mathrm{DCe} / \mathrm{DcE} \\
\mathrm{DCe} / \mathrm{cE} \\
\mathrm{DcE} / \mathrm{Ce}\end{array}$ & $\begin{array}{l}\mathrm{R}_{1} \mathrm{R}_{2} \\
\mathrm{R}_{1} \mathrm{r}^{\prime \prime} \\
\mathrm{R}_{2} \mathrm{r}^{\prime}\end{array}$ \\
\hline DCEe & $58(13.7 \%)$ & $\begin{array}{c}\text { DCE/DCe } \\
\text { Dce/cE } \\
\text { DcE/Ce }\end{array}$ & $\begin{array}{l}\mathrm{R}_{\mathrm{z}} \mathrm{R}_{1} \\
\mathrm{R}_{1} \mathrm{r}^{\prime \prime} \\
\mathrm{R}_{2} \mathrm{r}^{\prime \prime}\end{array}$ \\
\hline DCce & $40(9.5 \%)$ & $\begin{array}{c}\text { Dce/ce } \\
\text { Dce/Dce } \\
\text { Dce/Ce }\end{array}$ & $\begin{array}{c}\mathrm{R}_{1} \mathrm{r} \\
\mathrm{R}_{1} \mathrm{R}_{0} \\
\mathrm{R}_{0} \mathrm{r}^{\prime}\end{array}$ \\
\hline DCe & 35 (8.3\%) & $\begin{array}{l}\text { Dce/DCe } \\
\text { DCe/Ce }\end{array}$ & $\begin{array}{l}\mathrm{R}_{1} \mathrm{R}_{1} \\
\mathrm{R}_{1} \mathrm{r}^{\prime}\end{array}$ \\
\hline Dce & $6(1.4 \%)$ & $\begin{array}{l}\text { Dce/Dce } \\
\text { Dce/ce }\end{array}$ & $\begin{array}{c}\mathrm{R}_{0} \mathrm{R}_{0} \\
\mathrm{R}_{0} \mathrm{r}\end{array}$ \\
\hline $\mathrm{De}$ & 107 (25.4\%) & $\begin{array}{l}\text { De/De } \\
\text { De/e }\end{array}$ & $\begin{array}{c}\mathrm{R}_{0} \mathrm{R}_{0} \\
\mathrm{R}_{0} \mathrm{r}\end{array}$ \\
\hline D & $17(4.0 \%)$ & $\begin{array}{l}\text { D-/D- } \\
\text { D-/- }\end{array}$ & $\begin{array}{c}\mathrm{R}_{0} \mathrm{R}_{0} \\
\mathrm{R}_{0} \mathrm{r}\end{array}$ \\
\hline e & $7(1.7 \%)$ & $-e /-e$ & $r^{\prime} r^{\prime}$ \\
\hline null & $22(5.2 \%)$ & $-1-$ & $\mathrm{R}_{0}$ \\
\hline
\end{tabular}

Table-VI. The most probable genotypes among Aljouf population of Saudi Arabia

natural selection. Similarly, in agreement with previous studies $^{11,12,13}$.

The frequencies of $\mathrm{Rh}$ antigens; $\mathrm{D}$ frequency was related to that obtained among blacks (92\%) and Asians (99\%) populations, the c antigen frequency was like to Asians(47\%), C antigens frequency was like to Caucasians(68\%), E frequency was like to that obtained among Asians(39\%) while the e frequency was alike to Caucasians(98\%), Blacks(98\%) and Asians(96\%) populations ${ }^{14}$. In other studies done in ethnic nationalities of Calabar, Nigeria ${ }^{15}$, it was revealed that D was $95 \%$, C $17.7 \%$, c $99.8 \%$, e $98.7 \%$ and $\mathrm{E} 20.5 \%$. In a study by Thakral et al from India, e antigen was $98.3 \%$, D, C $84.7 \%$, c $52.8 \%$ and $\mathrm{E} 17.9 \%$ among blood donors ${ }^{16}$. In this study, it was found that the most common probable Rh-genotypes present in decreasing order of frequency were $R 1 R 2, R 1 r^{\prime \prime}, R 2 r^{\prime}$, R0R0, R0r, RzR1, R1r", R2r", R1r, R1R0, R0r', R1R1, $R 1 r$, R0, R0r, r'r'. This finding was in agreed to the study done ${ }^{17}$. And close to results that were obtained from Jordan ${ }^{18}$. Some genotypes of the Rh-system high frequencies of the ee, Ee, and cc versions were lower than those found by Marina et al. while, The Cc genotype carriers' frequency akin to that obtained by Marina et al. As for the CC genotype frequency was found among the Aljouf province only and not found in some studies. It is to be mentioned that the EE genotype is not generally present in aljouf population, and this finding was in agreement with other studies ${ }^{19}$. The Rh-antigens complexes present in this study; at most people belonging to Rwealy tribe had the complex DCce in agreement with frequencies reported in Caucasian, while in Shamary tribe, DCcEe was very dominant in contrary to report on whites and black populations ${ }^{14}$. The frequency of Rh null was similar in both Enazy (9.4\%) and Rwealy(8.7\%), this rare $\mathrm{Rh}$ phenotype was just found in Enazy and Rwealy because of their relatively and had a close system of marriage between them compared to the other ethnic groups of Aljouf region. Almost exactly 50 years ago, R.A.Fisher and R. Race proposed a model for the evolution of the $\mathrm{RH}$ (rhesus) genes in which the less common haplotypes were derived from the commoner ones by recombination, and in which the gene order was D-C-E. No direct evidence bearing on this model was available then, and has not been, until now ${ }^{20}$. The most probable haplotype frequencies in general the white group showed a close resemblance to those of the canary islands ${ }^{21}$ and Southern Spain ${ }^{22}$ with a nasty frequency of cDe haplotype and a towering frequency of cde. Negroes had the CDE haplotype, with moderately base frequency of $\mathrm{CDe}$ and elevated $\mathrm{CDe}$ frequency, distinctive from the majority of African samples $^{23}$. The CDE haplotype in the current study was unlike from that obtained in whites, mulattoes and Negroes. Whiles Cde was similar to all of them; cDe 
haplotype was found same as that among whites ${ }^{24}$.

The cdE haplotype in the instant study was absent in the population of South - western Germany ${ }^{25}$ and also in agreement to Pedro et al. findings. It is to be noted that the observed and expected frequencies of the $\mathrm{Rh}$ phenotype (CcDee) in the present study were similar to those previously reported by other workers in Germany $^{25}$. However, frequency of the CcDee phenotype among Amis, Japanese, Vietnamese, Sudanese, Lepchas and Khasis was lower than that of the Aljouf populations ${ }^{26,27,28,29}$.

\section{CONCLUSIONS}

The most frequently of Rh antigens occurring were $\mathrm{e}$ (91.0\%), D (93.1\%), C (62.3\%), C (41.7\%) and E (42.7\%). The collective probable Rh-genotypes present in decreasing order of frequency were R1R2, R1r", R2r', R0R0, R0r, RzR1, R1r", R2r", R1r, R1R0, ROr', R1R1, R1r', R0, R0r, r'r', r'r', RzR2, RzRz, r'r" and $r$ "r. The Rh antigens, alleles and phenotype frequencies within the population of Aljouf province; Saudia Arabia was different from those that were previously reported among the populations of Asian, African or European countries ${ }^{30}$. These differences may be of importance to the anthropologists, who are concerned with exploring the familiar populations based on the blood groups, and also in forensic medicine. The present study would provide the local Blood Transfusion Center in Sakaka city, Aljouf with the Rh blood types and frequencies that may play a role in the blood transfusion problems. From our point of view, the present study was original in that, it was the first comprehensive study that documented the distribution of frequency of Rhesus blood group alleles, haplotypes and genotypes in the Aljouf region of Saudia Arabia.

\section{RECOMMENDATION}

The data generated during this study would be helpful to the researchers within the field of population genetics to explore the factors responsible for the observed distribution patterns of these markers in this part of West Asia. Equally important, will be a base line for advance to be catalogued by molecular rather than serological criteria, and of polymorphisms between RHD and RHCE, which will be a useful for DNA typing and to provide the development of suitable DNA techniques. Further studies using complex antibodies and direct DNA analysis are recommended.

\section{ACKNOWLEDGMENTS}

We are grateful to Al-Jouf University, Vice Rector for Graduate Studies and Scientific Research for fund supports and all primary health centers (PHC) in the city of Sakaka for cooperation in this study. We are also pleased to the blood donors who cooperated with us in this study.

\section{Copyright $\odot 05$ Sep, 2013.}

\section{REFERENCES}

1. Daniels G, Poole J, Desilva, M, Callaghan T, Mac Leman $\mathrm{S}$, Smith $\mathrm{N}$. The clinical significance of blood group antibodies. Transfusion medicine; 2002;12:287-295.

2. Gates, MA; Wolpin, BM; Cramer, DW; Hankinson, SE; Tworoger, SS. Int J Cancer. 2011 Jan 15;128(2):482-6. Doi:10.1002/ijc.25339.Epub 2010 Marc 22.

3. Flegel WA, Khull SR, Wagner FF: Primary anti-D immunization by weak D type 2 RBCs. Transfusion 2000a; 40: 428-434.

4. Reid ME, Lomas-Francis C: The blood group antigen factsbook. 2nd Edition. Elsevier Academic Press, California, S.2004; 124.

5. Wagner FF, Ernst M, Sonneborn HH, Flegel WA: A D(V)like phenotype is obliterated by A226P in the partialD DBS. Transfusion . $2001 \mathrm{a}$; 41:1052-1058.

6. $\quad \mathrm{Xu} Q$, Zhang J, Wang $Q$, Zhang S, Si 0: RHD gene polymorphism among RliDnegative Han Chinese. Chin Med J. 2003; 116: 1539-1543.

7. Barry A., Aziza T., Joseph E., S. Gerald S. Successful Prevention of Post-Transfusion Rh Alloimmunization by Intravenous Rho (D) Immune Globulin (WinRho SD), Am. J. of Hem. 1999; 60: 245-247. 
8. Flegel WA, Wagner FF: Molecular genetics of RH. Vox Sang. 2000b; 2: 109-115.

9. Wagner T, K GF, Buchta C, Vandon M, Lanzer 0, Mayr WR, Legler TJ: Anti-D immunization by DEL red blood cells. Transfusion. 2005; 45:520-526.

10. Ahmed, S.G., M.B. Kangu and U.A.M. Abjah. 2009. The role of du testing in scaling down the burden of Rheusus-D negative transfusion in Nortehrn Nigeria. Int. J. Third World Med., Vol.8 Number2.

11. Bashwari LA, Al-Mulhim AA, Ahmad MS, Ahmed MA 2001. Frequency of $A B O$ blood groups in Eastern region of Saudi Arabia. Saudi Med J, 22(11): 10081012.

12. Hanania S, Hassawi D, Irshaid N 2007. Allele frequency and molecular genotypes of $\mathrm{ABO}$ blood group system in Jordanian population. J Med Sci, $7(1): 51-58$.

13. Sakharov RS, Nofal'Kh K 1996. The frequency of ABO blood groups and the expression of group antigens and isohemagglutinins in Syrian Arabs. Sud Med Ekspert, 39(2): 34-36.

14. Reid ME and Lomas-Francis C. The Blood Group Antigen Facts Book. Second ed. 2004, New York: Elsevier Academic Press.

15. Jeremiah ZA, Buseri Fl. Rh Antigen and Phenotype Frequencies and Probable Genotype for the Four Main Ethic Groups in Port Harcourt, Nigeria. Immunohematology 2003; 19(3): 86-8.

16. Thakral B, Saluja K, Sharma RR, et al. Phenotype Frequencies of Blood Group System (Rh, Kell, Kidd, Duffy, MNSs, P, Lewis and Lutheran) in North Indian Blood Donors. Transfus Apher Sci 2010; 43(1): 17-22.

17. Otto Hartmann A. E. Mourant, R. R. Race. THE Rh GENOTYPES OF A SERIES OF OSLO BLOOD DONORS Acta Pathologica Microbiologica Scandinavica.1947; Vol 24 Issue 3-4.

18. Jabal A, Shubeilat T. The Frequency of Rhesus Phenotypes at King Hussein Medical Center. JRMS 2003; 10(1): 53-5.
19. Marina Nagervadze, Rusudan Khukhunaishvili, Anzor Diasamidze, Marina Koridze, Guguli Dumbadze, Leila Akhvlediani. Characteristics of the Frequency Distribution of some Immunogenic Markers in the Population of the Mountain Region (Khulo) of Ajara. BULLETIN OF THE GEORGIAN NATIONAL ACADEMY OF SCIENCES, vol. 3, no. 2, 2009.

20. Carritt, B., Kemp T. J., and Poulter M. Evolution of the human RH (rhesus) blood group genes: a $\mathbf{5 0}$ year old prediction (partially) fulfilled Human Molecular Genetics, 1997; 6(6): 843-850.

21. Planas J., Fuste, M., Diaz, J.M. and Pons, J. Blood groups (Rh, $A B 0)$ in thev population of Gran Canaria(Canary Islands, Spain). Hum. Hered. 19: 185 -189 .

22. Valls, A. Seroantropologia de la poblacion Espanola. Rev. Univ. Complutense XXXIV; 1975(97) 111-139.

23. Mourant, A.E., Koppec, A.C. and DomaniewskaSobczak, K. The distribution of the Human Blood Groups and other polymorphisms. 2nd ed. Oxford University Press, London; 1976.

24. Pedro C., Jose F., Tomas C., Antonion M., Miriam C., Ruslinda O. Distributor of ABO, Rh, MN and Kell blood groups in Central Cuba, Brazilian Journal of Genetics. 1995; 18, 3, 475-478.

25. Wagner FF, Kasulke D, Kerowgan M, Flegel WA. Frequencies of the blood groups ABO, Rhesus, D category VI, Kell, and of clinically relevant highfrequency antigens in south-western Germany. Rfusionsther Transfusionsmed. 1995 0ct;22(5):28590.

26. Ikemoto S, Ming CT, Haruyama N, Furuhata T. Blood group frequencies in the Ami Tribe (Formosa) Proc Jpn Acad. 1966;42:173-7.

27. Ikemoto $S$, Watanabe $S$, Ogawa $R$, Furuhata $T$. Frequencies of blood groups among Vietnamese. Proc Jpn Acad. 1966;42:975-9.

28. Miki T, Tanaka T, Furuhata T. On the distribution of the MN, $\mathbf{Q}$ and $\mathbf{R h}$ blood types of the Lepchas and the Khasis. Proc Jpn Acad.1960;36:168-71. 
29. Roberts DF, Ikin EW, Mourant AE. Blood groups of the northern Nilotes. Ann Hum Genet. 1955;20:135-54.

30. Eweidah M. H., Shaik R., Hassan A. Al-Shamary A. Distribution of $A B O$ and Rhesus (RHD) Blood Groups in Al-Jouf Province of the Saudi Arabia. Anthropologist, 2011; 13(2): 99-102 (2011).

31. Al-Sheikh IM, Zaid SZA, Islam SIA, et al. Frequency of Various Rh Antigens in Dammam Eastern Province, Saudi Arabia. Saudi Med J 1998; 19(3): 265-8.

32. Flegel WA: Molecular genetics of RH and its clinical application. Transfus Clin Biol. 2006; 13: 4-12.

33. Jeremiah ZA, Odumody C. Rh antigens and phenotype frequencies of the Ibibio, Efik, and Ibo ethnic nationalities in Calabar, Nigeria. Immunohematology. 2005;21(1):21-4.
34. Kurexijiang T, Hamulati W, Nuermaimaiti $Y$, et al Comparative Investigation of $\mathbf{R h}$ Blood Type Distribution between the Uygur and Han Nationalities in the Khotan Area of Xinjiang Autonomous Region. Di Yi Jun Yi Da Xue Xue Bao 2004; 24(4): 447-9.

35. Mawuagi J. Blood group distribution in an urban population of patient targeted blood donors. East Afr. Med. J. 1999; 76(1 I):615 - 618.

36. Omotade, Adeyem AA, Kayode CM, Falade SL, Ikpeme $\mathrm{S}$. Gene frequencies of $\mathrm{ABO}$ and $\mathrm{Rh}$ (D) blood group alleles in a healthy infant population in Ibadan, Nig. West Afr. J. Med. 1999; 18:294-297.

37. Younis Abed EL-Wahhab Skaik1, Nermeen R. El-Zyan2 Spectrum of $A B O$ and $R h$ (D) blood groups amongst the Palestinians students at al-Azhar University Gaza. Pak J Med Sci. 2006; 22: 3 333-335.

\section{AUTHOR(S):}

1. DR. HAMID MAHMOOD

Associate Professor of Biochemistry

Frontier Medical College, Abbottabad.

2. DR. SITARA HASSAN

3. DR. HASHIM RIAZ

Assistant Professor of Community Dentistry

Frontier Medical College, Abbottabad.

4. Dr. Waseem Akhtar
Correspondence Address:

Dr. Hamid Mahmood

Professor of Bio Chemistry,

Islam Medical and Dental College, Sialkot. drhamidmahmood373@gmail.com

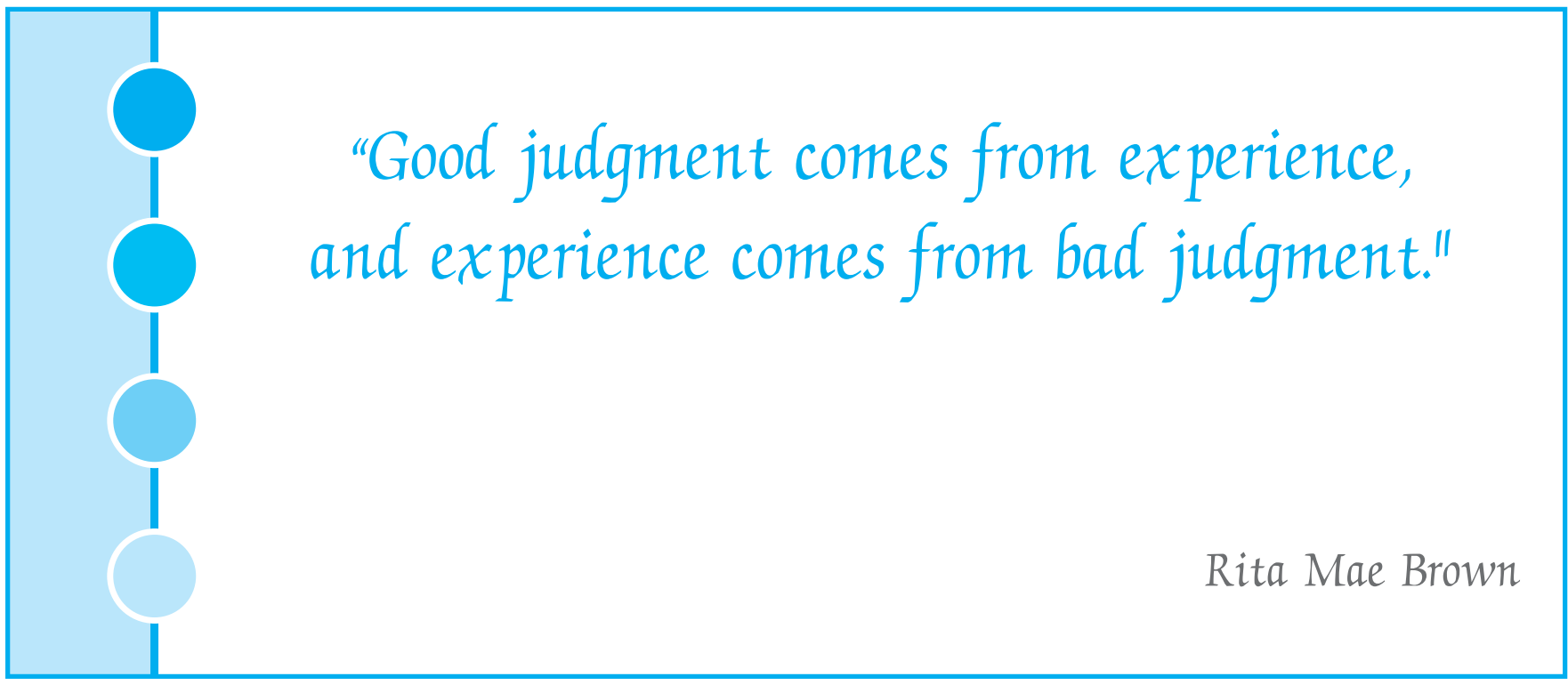

